\title{
FADING MECHANISM OF REACTIVE DYES ON CELLULOSE BY SIMULTANEOUS EFFECT OF LIGHT AND PERSPIRATION
}

\author{
By Yasuyo Okada, ${ }^{* 1}$ Toshiko Kato, ${ }^{* 1}$ Hiromi Motomura, ${ }^{* 2}$ and Zenzo Morita ${ }^{* 2}$ \\ *1 School of Domestic Science, Ohtsuma Women's University, \\ Sanban-cho, Chiyoda-ku, Tokyo, 102 Japan \\ *2 School of Engineering, Tokyo University of Agriculture and \\ Technology, Koganei, Tokyo, 184 Japan
}

\begin{abstract}
Fading of vinylsulfonyl (VS) reactive dyes on cellulose by simultaneous effect of light and perspiration was studied by exposing dyed fabrics by 'A' method of JIS L 0888 and dyed films in aqueous solutions. A significant fading was observed with the dyed film in an aerated aqueous solution of sodium DL-mandelate and lactate. The fading process was accelerated in the anaerobic solution with a few exceptions. The fading of a dye on cellophane film in the anaerobic solution of substrate such as DL-mandelate was photoreduction of the excited dye by the substrate. On exposure in the solution containing both oxy. gen and substrate, the photosensitized oxidation of a dye via singlet oxygen mechanism and/or the photoreduction were found to occur depending on the experimental conditions such as concentrations of oxygen and substrate. The photofading mechanism of VS dyes on cotton fabrics immersed previously in an aqueous solution of artificial perspiration and exposed by the method of JIS L 0888 was similar to that on film exposed in the solution, although there were some differences between their fading behaviors.
\end{abstract}

\section{INTRODUCTION}

With development of reactive dyes, some of their disadvantages have been noticed, ${ }^{1,2\}}$ such as rather poor wet fastness, poor chlorine fastness, poor fastness to the simultaneous effect of light and perspiration. To reproduce the simultaneous effect of light and perspiration on the fading of reactive dyes in the practical usage, a testing method for color fastness to light and perspiration was established as the one in the Japanese Industrial Standard ${ }^{3)}$ in 1977. In order to avoid the consumers' claims based on the simultaneous effect, some workers ${ }^{4-6)}$ have made extensive studies to select the reactive dyes with higher fastness to light and perspiration.

Recently, some members of the Association for Textile Technology Study ${ }^{7-9)}$ (ATTS) have confirmed that the testing method of JIS L $0888^{3)}$ was insufficient to predict the consumer's performance of reactive dyes for light and perspiration. They reported that the addition of lactic acid, panthotenic acid, aspartic acid and glucose to the artificial perspiration of JIS L $0848^{10}$ ) was necessary to reproduce the con. sumers' claims. They also implied the existence of a reduction process in the fading by simultaneous effects of light and perspiration. ${ }^{7-9}$ )

The authors reported that vinylsulfonyl (VS) reactive dyes on cellulose in water was faded by photooxidation in the absence of substrate. ${ }^{11)}$ They also studied the role of components of the ATTS artificial perspiration in the simultaneous effect of light and perspiration on the fading of VS dyes. ${ }^{12)}$ It was found that lactic acid, histidine and glucose accelerated the fading on exposure to light and that aspartic acid and panthotenic acids retarded it if used in a mixture with other components of perspiration such as lactic acid.

When effects of substrates such as lactic acid, histidine or glucose on the fading of VS dyes on waterswollen cellulose and on cotton fabrics were examined, they have some similarities to the effect of substrate such as mandelic acid on the reductive fad. ing of azo dyes, ${ }^{13-22)}$ that of various amines on the photoreduction of copper phthalocyanine ${ }^{23,24)}$ and 
photosensitized oxidation of amines ${ }^{25-28)}$ and amino acids. $^{29-32)}$ Bartholomew and Davidson ${ }^{25)}$ proposed the mechanism of the two types of photosensitized reaction for amines. Putting all the results reported together and extending this scheme for substrate other than amines, the present authors propose a mechanism for the photosensitized fading of dye as shown in Scheme 1 and prove it in the present paper:

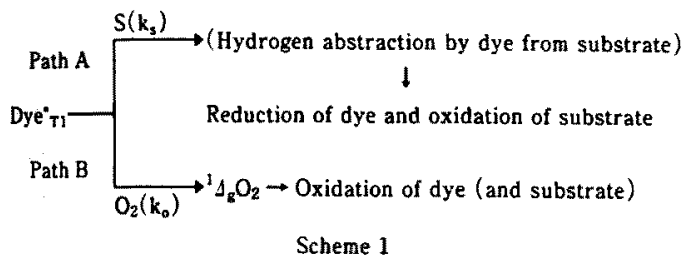

where $S$ denotes substrate, Dye ${ }^{*} T_{1}$ is the excited triplet of dye, $k_{\mathrm{s}}$ and $k_{0}$ are the rate constants of reac tion of dye with substrate and oxygen, respectively. Path $A$ gives a reductive photobleaching of dye by the self-excitation and Path $B$ an oxidative one by singlet oxygen generated by the sensitization of the partner dye and/or by the self-sensitization. The authors previously reported on $P a t h B$ that although all the VS dyes examined had the photosensitivity the rate of fading depended on mainly the ease with which the dye was oxidized. ${ }^{33}$ ) The extent to which reaction will occur by one particular path is determined by the ratio of $k_{s}$ to $k_{0}$ and the concentration of substrate and oxygen, ${ }^{25)}$ although the values of $k_{s}$ and $k_{0}$ depend on the properties and the combination of dye and substrate. At the same time, some substrates may act as a quencher of singlet oxygen for the dye oxidation. ${ }^{34-36}$ It is known that anaerobic conditions accelerate $P$ ath $A$ and inhibit $P$ ath $B$, while aerobic ones accelerate $P$ ath $B$ and retard $P$ ath $A{ }^{37,38 \text { ) }}$

In the present paper, the authors prove Scheme 1, especially Path $A$, by showing the similarities between the effect of substrate such as mandelic acid on reductive fading in various solutions and the effect of lactic acid on fading of C.I. Reactive Red 22 and Black 5 dyed on cellulose films and fabrics by re. garding the perspiration as a mixture of substrates to cause photoreduction of dyes on cellulose. At the same time, the simultaneous effect of light and perspiration on the fading of reactive dyes on cellulose is shown to depend on the properties of individual dyes, thus the fading is proved to be attributed either to the photoreduction by the substrate or to the photooxidation by singlet oxgen.

\section{EXPERIMENTAL}

\subsection{Dyes Used}

VS dyes used were same as before. ${ }^{12)}$ They have the following chemical structure:

1) Aminopyrazolinyl azo dye (Yellow)

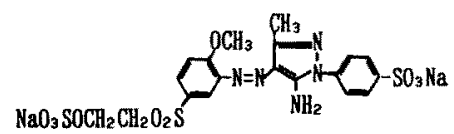

2) C. I. Reactive Red 22 (Red 22)

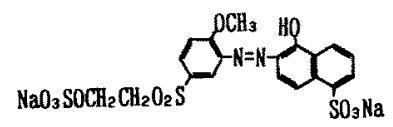

3) Cu-Complex azo dye (Blue-Cu)

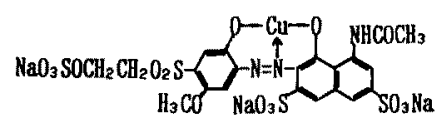

4) Copper phthalocyanine dye (Cu-Pc)

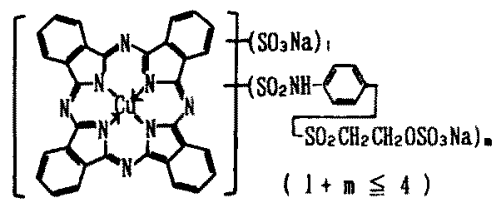

5) C. I. Reactive Blue 19 (Blue 19)

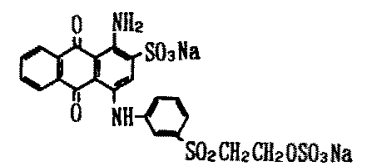

6) C. I. Reactive Black 5 (Black 5)

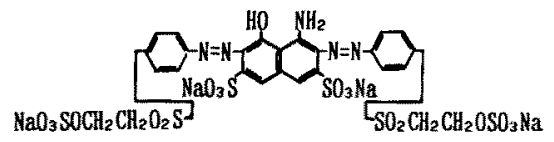

The sample for dyeing and the dyeing method of cotton fabrics and cellophane films were also same as before. ${ }^{12.33)}$ The cellophane films were dyed in weakly alkaline dyebath or by the alkali-shock method for Yellow. Cotton fabrics were dyed in a bath of liquor ratio $30: 1$ with $1.0 \%$ o.w. f. dye, $50 \mathrm{~g} / \mathrm{dm}^{3}$ sodium sulfate and $20 \mathrm{~g} / \mathrm{dm}^{3}$ sodium carbonate at $50^{\circ} \mathrm{C}$ for 90 min. After dyeing, they were soaped in boiling water containing non-ionic surfactant (Scourol 400 (Kao Corp.)]. 


\subsection{Method of Exposure}

The dyed fabrics were exposed by ' $A$ ' method of IIS L $0888^{3)}$ to the carbon-arc lamp $(>290 \mathrm{~nm})$ in a fade-ometer (Model FAL-3, Suga Test Instruments Co.). The fabrics were immersed in various solutions before exposure. The values of psychometric lightness and chromaticness for the irradiated and original fabrics were measured by a spectral color meter (Model MSC-IS-2B, Suga Test Instruments Co.), from which the color difference during the exposure was obtained.

The dyed film was set on the inner surface of a glass cell filled with aqueous solution at $50^{\circ} \mathrm{C} .{ }^{11)}$ The glass cell was fixed on a cell holder placed in a glass vessel and was exposed to the carbon-arc lamp in the same fade-ometer. The cell holder with which a glass vessel was equipped was made by modifying a sample holder for JIS L. $0888^{11}$ (Fig. 1). Under the deaerated conditions a pair of two sheets of cellophane of the same size as the sample, all the films of which were previously impregnated by the DL-mandelate or lac-

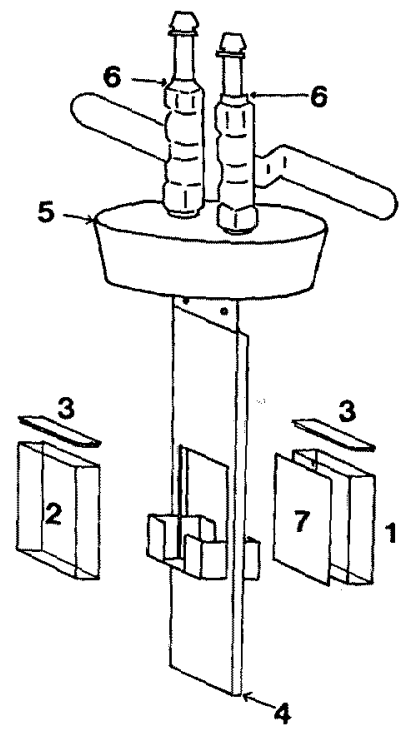

Fig. 1. Glass cell holder for exposure. The holder was equipped with a silicone rubber stopper $(\phi=70 \mathrm{~mm})$, which was placed in a glass vessel. The glass vessel was set in a carbon-arc fade-ometer. ${ }^{1)} 1$, Glass cell for sam. ple: 2, glass cell for liquid filter (usually water); 3 , Tef. lon stopper for glass cell; 4 , holder for glass cell; 5 , sili cone rubber stopper for glass vessel of JIS L $0888 ; 6$, gas inlet or outlet pipe with cock: 7, filter. tate solution, was set in front of and behind the sam. ple film (total: five sheets) inside the front glass of a glass cell for exposure. On the rear side of the films, a glass plate was put for preventing penetration of trace oxygen. Nitrogen of ordinary pressure was fil. led in a glass vessel in which the glass cell was set. Under the aerated conditions, a sheet of the dyed film was set inside the front glass of a glass cell for exposure.

The relative fading, $A / A_{0}$ where $A_{0}$ and $A$ are the optical densities before and after exposure respective. $\mathrm{ly}$, was estimated at the wavelength of the maximum absorption except for $\mathrm{Cu}-\mathrm{Pc}$, which was done by a use of the isosbestic point. Chemicals used were of reagent grade. $\beta$-Hydroxyethylsulfonylaniline derivatives were supplied by Mitsubishi Chemical Corporation. For minimizing hydrolysis of dye-fiber bond. DL-mandelic acid and lactic acid were neutralized to be weakly acidic $(\mathrm{pH}=$ ca. 6$)$.

\section{RESULTS AND DISCUSSION}

\subsection{Fading of Red 22 and Black 5 on Film in Sub- strate Solutions}

The fading behaviors of Black 5 were initially examined in aqueous aerated solutions containing va. rious amounts of sodium DL-mandelate and in the anaerobic solutions in nitrogen atmosphere. The results are shown in Fig. 2. The rate of fading for Black 5 was proportional to the concentration of sodium DL-mandelate. The fading was considerably accelerated by the anaerobic conditions but was not retarded by oxygen-saturated solution.

The rate of fading for Red 22 and Black 5 was also proportional to the concentration of sodium lactate in aqueous aerated solutions (Fig. 3). As in the case of sodium DL-mandelate, the anaerobic conditions accelerated the fading of the both dyes. The rate of fading for Red 22 was greater than that for Black 5 . The effect of sodium DL-mandelate on the fading for both dyes was stronger than that of sodium lactate. Thus, Red 22 and Black 5 on cellulose swollen in an aqueous solution containing substrate showed similar fading behavior to that in DL-mandelate solutions investigated by van Beek et al. ${ }^{13-17}$ )

According to van Beek et al. ${ }^{13-20\rangle}$ sodium DL-mandelate reduces azo groups in azo dyes on exposure to 


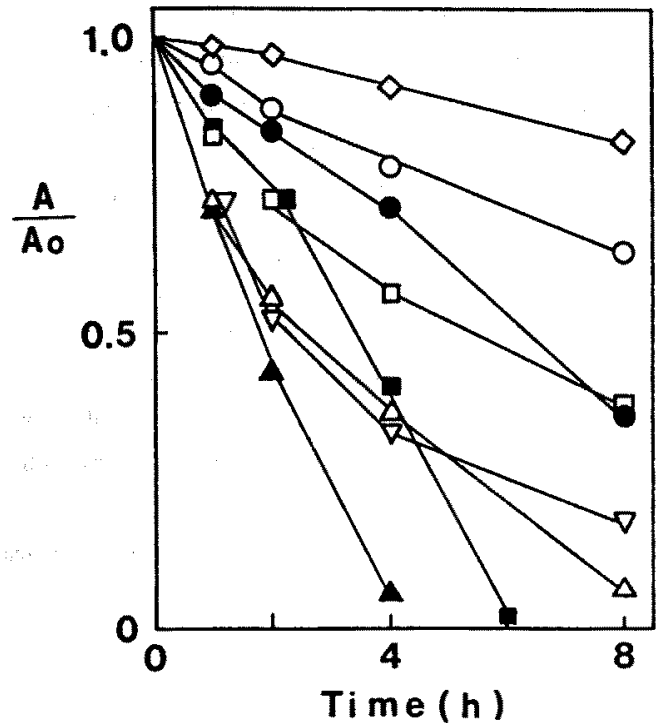

Fig. 2. Fading of C. I. Reactive Black 5 on cellulose on exposure in aqueous aerated sodium DL-mandelate solutions $(\mathrm{pH} \mathrm{6.0)}$ and in the anaerobic solutions under nitrogen atomosphere. Sodium chloride $\left(0.05 \mathrm{~mol} / \mathrm{dm}^{3}\right)$ was added to all solutions.

\begin{tabular}{ccc}
\hline Conc. of Na DL-mandelate & Aerobic soln. & Anaerobic soln. \\
\hline $0.02 \mathrm{~mol} / \mathrm{dm}^{3}$ & 0 & \\
0.05 & $\square$ & \\
0.10 & $\Delta$ & \\
\hline
\end{tabular}

$0.10(\nabla)$ in oxygen-saturated solution under oxygen atmosphere

$0.10(\diamond)$ in aerobic solution on exposure with a Toshiba $\mathrm{R}-60(>600 \mathrm{~nm})$ filter

form aniline and/or naphthylamine derivatives. Blaisdel ${ }^{39)}$ who studied the photofading of azo dyes in organic solvents, showed that the fading reaction consisted in the addition of hydrogen, extracted from the solvent, to the azo linkage to form a substituted hydrazine as an intermediate and later substituted anilines. Only the azo form of azo dyes is considered to be reduced. In case of reactive azo dyes, the aniline derivatives produced may be kept to bind with cellu. lose.

The photochemical reduction is inhibited by oxy$\operatorname{gen}^{37.38)}$ as is obviously shown in Figs. 2 and 3 . Azo groups in the excited dye extracts hydrogen from substrate to yield hydrazyl radical. ${ }^{13,15.19,201}$ It may react further with hydrogen to give hydrazine, or may react with singlet oxygen to revert to the original

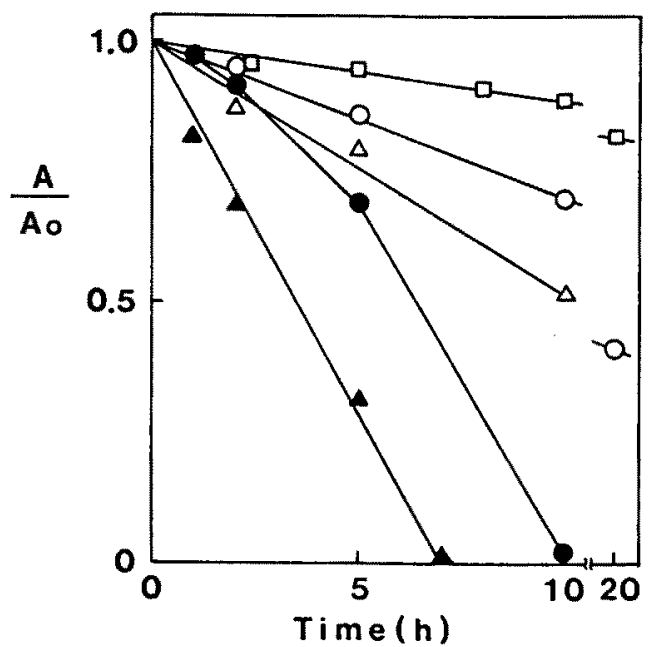

Fig. 3. Fading of C.I. Reactive Red 22 and Black 5 on cellulose on exposure in aqueous aerated sodium lactate solutions ( $\mathrm{pH}$ 6.1) and in the anaerobic solutions under nitrogen atomosphere.

Sodium chloride $\left(0.05 \mathrm{~mol} / \mathrm{dm}^{3}\right)$ was added to all the solutions.

\begin{tabular}{clcc}
\hline Dye & Conc of Na lactate & Aerobic soln & Anaerobic soln. \\
\hline Red 22 & $0.50 \mathrm{~mol} / \mathrm{dm}^{3}$ & $\triangle$ & $\Delta$ \\
Black 5 & 0.05 & $\square$ & - \\
Black 5 & 0.50 & $\bigcirc$ & $\triangle$ \\
\hline
\end{tabular}

form. In this case, Path A may be suppressed by singlet oxygen generated in Path $B$ and in turn Path $B$ may be suppressed by this process.

On the other hand, Griffiths and Hawkins ${ }^{40-42}$ reported that singlet oxygen oxidizes the hydrazone form of azo dyes to break the azo group and yields an oxyphenyl derivative, which may also be kept to bind with cellulose in the present case.

In order to examine the degradation product bound with cellulose, the UV-spectra of the film were obtained after considerable fading. The UV-spectra of Black 5 exposed in the aerated DL-mandelate and lactate solutions were similar to each other as shown in Fig. 4, while those of Red 22 exposed in their deaerated solutions showed similar behavior (Fig. 5). The spectrum for Black 5 had two characteristic absorption bands at 267 and $200 \mathrm{~nm}$ with a shoulder at 215 $\mathrm{nm}$, which was similar to that of $4-\beta$-hydroxyethyl. sulfonylaniline in water $\left(\lambda_{\max }=264\right.$ and $195 \mathrm{~nm}$ with a shoulder at $210 \mathrm{~nm}$ ), while that for Red 22 three 


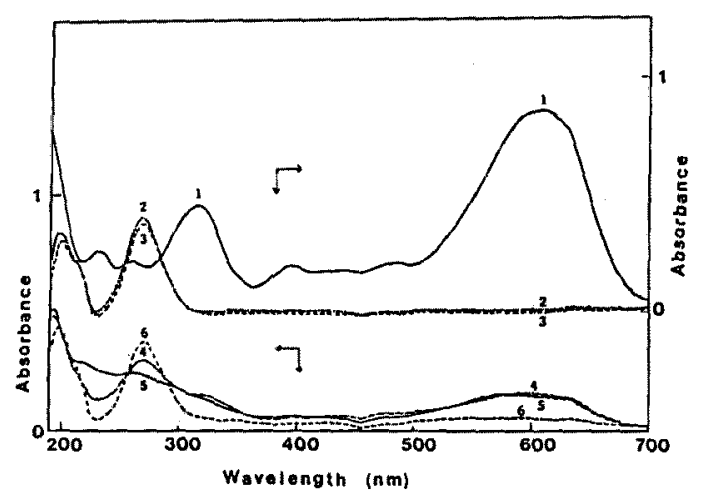

Fig. 4. Absorption spectra of Black 5 on cellophane before (1) and after an exposure in aqueous solutions: anaerobic soln. of $\mathrm{Na}$ lactate $\left(0.50 \mathrm{~mol} / \mathrm{dm}^{3}\right)$ for $10 \mathrm{~b}$ (2), anaerobic soln. of $\mathrm{Na} \mathrm{DL-mandelate}\left(0.10 \mathrm{~mol} / \mathrm{dm}^{3}\right)$

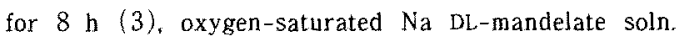
$\left(0.10 \mathrm{~mol} / \mathrm{dm}^{3}\right)$ for $8 \mathrm{~h}(4)$, aerated soln. of $\mathrm{RB}(3.3 \times$ $\left.10^{-5} \mathrm{~mol} / \mathrm{dm}^{3}\right)$ for $36 \mathrm{~h}(5)$, and aerated soln. of $\mathrm{Na}$ $\mathrm{DL}$-mandelate $\left(0.10 \mathrm{~mol} / \mathrm{dm}^{3}\right)$ for $8 \mathrm{~h}(6)$.

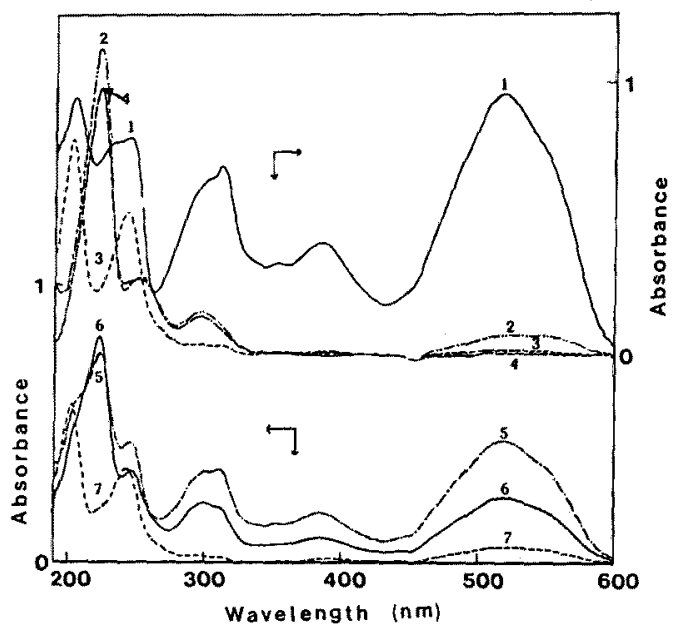

Fig. 5. Absorption spectra of Red 22 on cellophane be fore (1) and after an exposure for $8 \mathrm{~h}$ in aqueous solutions: anaerobic $\mathrm{Na}$ DL-mandelate soln. $\left(0.10 \mathrm{~mol} / \mathrm{dm}^{3}\right)$ for $6 \mathrm{~h}(2)$, aerated $R B$ soln. $\left(3.3 \times 10^{-5} \mathrm{~mol} / \mathrm{dm}^{3}\right)$ for $26 \mathrm{~h}(3)$, anaerobic $\mathrm{Na}$ lactate soln. $\left(0.50 \mathrm{~mol} / \mathrm{dm}^{3}\right)$ in $\mathrm{N}_{2}$ atmosphere for $7 \mathrm{~h}(4)$, aerated $\mathrm{Na}$ lactate soln. $(0.50$ $\left.\mathrm{mol} / \mathrm{dm}^{3}\right)$ for $10 \mathrm{~h}(5)$, aerated $\mathrm{Na} \mathrm{DL}-$ mandelate soln. $\left(0.05 \mathrm{~mol} / \mathrm{dm}^{3}\right)$ for $10 \mathrm{~h}(6)$, and oxygen-saturated $\mathrm{Na}$ DL-mandelate soln. $\left(0.05 \mathrm{~mol} / \mathrm{dm}^{3}\right)$ for $10 \mathrm{~h}(7)$.

bands at 298,254 and $223 \mathrm{~nm}$ with increasing the absorption, which was almost similar to that of $5-\beta$ hydroxyethylsulfonyl-2-anisidine in water $\left(\lambda_{\max }=\right.$ 296, 253, and $219 \mathrm{~nm}$ ) (Fig. 5).
The absorption spectra for Black 5 and Red 22 on film after exposure in an aqueous aerated solution containing Rose Bengal ( $R B$ ) showed also characteristic bands (two peaks at 205 and $220 \mathrm{~nm}$ for Red 22 and a broad band with a peak at $200 \mathrm{~nm}$ with shoul. ders at 220 and $260 \mathrm{~nm}$ for Black 5). The UV-spectra for Red 22 and Black 5 after the disappearance of visible absorption by exposure gave a sufficient evidence to show which reaction, the photoreduction or photo-oxidation, occurred and the existence of aromatic ring in the substrate, a preservation of dye-fiber bond.

The presence of amino groups in cellulose, which was contained in a degradation product of Red 22 and Black 5 exposed in DL-mandelate or lactate solution, was proved by the diazotization reaction followed by the coupling with $\beta$-naphthol or Naphthol AS and by the reaction with 2,4-dinitrofluorobenzene which yielded the specific color or the absorption spectrum. respectively. No reaction was confirmed to occur by both methods for the films exposed in aerated solu. tion with and without RB. This shows that on an exposure, DL-mandelate or lactate reduces the azo group of both dyes to give the corresponding aniline derivative which is bound with cellulose via vinylsulfonyl group.

In principle, the photo-oxidation and the photoreduction may be concurrent depending on the extent given by the values of $\mathrm{k}_{o}$ and $\mathrm{k}_{\mathrm{s}}$ in Scheme 1. In fact. the photoreduction of Black 5 was found to occur in the aerated solution of $\mathrm{DL}$-mandelate or lactate. The UV-spectra of Black 5 during the fading showed a sufficient evidence of the small amount of oxidation product under all conditions examined (Fig. 4). In the case of oxygen-saturated solution, the spectra of the exposed film showed the occurrence of both oxidative and reductive products. The increase in the concentration of DL-mandelate in the oxygen-saturated solution increased the proportion of the reductive product compared with the case of DL-mandelate solution of lower concentration.

Since Black 5 has two azo groups, there may be a monoazo intermediate of bluish-red, which was observed on the fading after immersing in a neutral sodium lactate solution and not observed at low $\mathrm{pH}^{\left({ }^{12}\right)}$ in cellulose during fading. Similar fading making cot- 
ton fabrics to be bluish-red was also observed in the present study with sodium DL-mandelate (cf. 3. 4). Although the exposure of Black 5 was examined in lactate solutions up to $\mathrm{pH} 10$, such an intermediate was not detected under the experimental conditions examined. It implies that the monoazo intermediate may be very readily reduced in water.

On the other hand, Red 22 mainly yielded the reductive product with a trace of oxidative one on the exposure in the aerated lactate $\left(0.5 \mathrm{~mol} / \mathrm{dm}^{3}\right)$ and DL-mandelate $\left(0.05 \mathrm{~mol} / \mathrm{dm}^{3}\right)$ solutions, and the oxidative one with a trace of the reductive one in the oxygen-saturated DL-mandelate $\left(0.05 \mathrm{~mol} / \mathrm{dm}^{3}\right)$ solution, respectively. On the exposure in the oxygensaturated DL-mandelate solution, Red 22 mainly gave the oxidative product, while Black 5 the reductive one.

\subsection{Fading of Other VS Dyes on Film in DL-Mande- late Solution}

For comparing the fading behavior in sodium DL-mandelate solution for six VS dyes on film with the oxidative fading ones in aerated water, the values of $\mathrm{A} / \mathrm{A}_{0}$ estimated under various conditions are shown in Table 1. The effect of the aerobic and anaerobic conditions on the rate of fading varied with

Table 1 Relative Fading, A/A $(-)$, of Vinylsulfonyl Dyes on Cellophane in Aqueous DL-Mandelate Solutions after Exposure for $4 \mathrm{~h}$ and in Aerated Water for $8 \mathrm{~h}$

\begin{tabular}{lllllll}
\hline \multicolumn{1}{c}{ Dyes } & $\begin{array}{c}\text { Conc. } \\
\times 10^{2}\end{array}$ & $\begin{array}{c}\text { Water } \\
(8 \mathrm{~h})\end{array}$ & \multicolumn{3}{c}{$\begin{array}{c}\text { Sodium DL-mandelate } \\
\left(0.05 \mathrm{~mol} / \mathrm{dm}^{3}, 4 \mathrm{~h}\right)\end{array}$} \\
& $\begin{array}{cccccc}(\mathrm{mol} / \mathrm{kg}) \\
\text { in air }\end{array}$ & in $\mathrm{N}_{2}$ & in air & in $\mathrm{O}_{2}$ \\
\hline Yellow & 1.58 & 0.722 & 1.00 & 0.901 & 0.809 \\
Red 22 & 2.18 & 0.505 & 0.174 & 0.631 & 0.279 \\
Blue-Cu & 1.36 & 0.897 & $0.118^{* 1}$ & 0.287 & 0.615 \\
Cu.Pc & 0.564 & 0.955 & 0.809 & 0.853 & 0.851 \\
Blue 19 & 1.21 & 0.988 & 0.966 & 0.950 & 0.941 \\
Black 5 & 0.567 & 0.920 & 0.414 & 0.568 & 0.568 \\
\hline
\end{tabular}

The values of $A / A_{0}$ in deaerated water in nitrogen atmosphere were null for all the VS dyes examined. (A sheet of dyed film was placed in a glass cell filled with deaerated water. On the rear side of film a glass plate was put to prevent the penetration of trace oxygen.)

* 1) Since the film was faded with spots, the value of highest fading was given in the table and that of lowest fading was 0.385 . dyes. Under the anaerobic conditions, the reductive fading was found to occur exclusively in the presence of DL-mandelate. No photofading was observed for these VS dyes on cellulose on the exposure in deaer. ated water in nitrogen atmosphere. Singlet oxygen mechanism on Path B was previously found to hold in the photofading of VS dyes on cellulose under wet conditions by diagnostic tests. ${ }^{11.33)}$

Yellow showed no fading in the anaerobic DL-mandelate solution and an increasing tendency in the fading with an increase in the concentration of oxygen. The UV-spectra of Yellow after fading in the aerated DL-mandelate solution was similar to those after fading in aerated water. It indicates that Yellow is subject only to oxidative fading in aqueous solu. tions. DL-Mandelate suppressed the fading of Yellow compared with the rate of fading in aerated water, showing that the substrate acted as an inhibitor of oxidative fading.

Blue- $\mathrm{Cu}$ had the highest rate of fading in the deaer. ated and aerated DL-mandelate $\left(0.05 \mathrm{~mol} / \mathrm{dm}^{3}\right)$ solutions in the VS dyes examined but the reductive fading of Blue-Cu was strongly inhibited by oxygen. Blue $-\mathrm{Cu}$ is readily reductive but is oxidative to a less extent. The UV-spectrum of Blue-Cu (four peaks at $\lambda_{\max }=306,264,231$, and $209 \mathrm{~nm}$ with increasing the absorption) after exposure in the anaerobic DLmandelate solution was similar to that of the reductive product for Red 22 and that of 4 - $\beta$-hydro. xyethylsulfonyl-2,5-dimethoxyaniline in water ( $\lambda_{\max }$ $=303,262,226$, and $206 \mathrm{~nm}$ ), although the degradation product of Blue-Cu might be the 2-hydroxyl compound. The degradation products of Blue- $\mathrm{Cu}$ exposed in the DL-mandelate solution showed a sufficient proof of amino group in cellulose. They reacted with 2,4-dinitrofluorobenzene and was developed by $\beta$ naphthol to give their specific absorption spectrum or color, respectively, No reaction of the degradation product of Blue-Cu exposed in the aerated RB solution with 2,4-dinitrofluorobenze was confirmed. Blue$\mathrm{Cu}$ was faded with spots and these fading behaviors remain to be studied.

Light-induced, reversible one-electron reduction of $\mathrm{Cu}-\mathrm{Pc}$ is known to take place very readily on fabrics in the presence of amines such as textile resin. ${ }^{23.24}$ ) The color of $\mathrm{Cu}-\mathrm{Pc}$ on the film was changed to violet 
during the exposure in the deaerated and aerated DL-mandelate solution, whose color shows the presence of reduction process and returned immediately to the original one after taking out the film from the solution. This color change of $\mathrm{Cu}-\mathrm{Pc}$ was also observed with cotton fabrics exposed by 'A' method of $L 0888$ with artificial perspiration. ${ }^{12)}$ In the oxy gen-saturated solution, $\mathrm{Cu} \cdot \mathrm{Pc}$ kept the original color. On exposure $\mathrm{Cu} \cdot \mathrm{Pc}$ may be mainly faded by the reduction in the deaerated and aerated DL-mandelate solution and by oxidation in the oxygen-saturated mandelate solution. $\mathrm{Cu}-\mathrm{Pc}$ on fabrics may be mainly faded by the oxidation in the initial period of exposure when water is present on fabrics and by the re duction in the subsequent period (cf. 3.4).

The fading of Blue 19 was accelerated by DLmandelate. It appears to be an additive effect of both the oxidative and reductive attacks. Red 22 is subject to both processes, as shown above. Blue- $\mathrm{Cu}, \mathrm{Cu}-\mathrm{Pc}$ and Black 5 are subject more to reductive attack than to oxidative one, indicating the retarding effect of reduction by oxygen.

From the values of $A / A_{0}$ after fading shown in Table 1, the order for the rate of oxidative fading was: ${ }^{33}$

Red $22>$ Yellow $>$ Blue-Cu $>$ Black $5>$

$\mathrm{Cu}-\mathrm{Pc}>\mathrm{Blue} 19$

and that for the rate of reductive fading was:

Blue $-\mathrm{Cu}>\operatorname{Red} 22>$ Black $5>\mathrm{Cu} \cdot \mathrm{Pc}>$

Blue $19>$ Yellow

The order (2) is different from that for the rate of fading of VS dyes on cotton fabrics immersed in the ATTS artificial perspiration. The hypothesis that the hydrazone form of azo dyes is oxidized and the azo form is reduced seems to hold only for Yellow. High rates of both oxidative and reductive fadings for Red 22 can be attributed to the highest photosensitivity. ${ }^{33}$ ) Except for Yellow, readily oxidized dyes were at the same time reduced with ease. Since the rate of fading for VS dyes in the DL-mandelate solution varied with the concentration of oxygen and the tendency of the effect of oxygen does also with dyes, the apparent rate of the oxidative and reductive fading may vary with the experimental conditions. The reason why these dyes have such properties remains to be further studied. The degradation products of $\mathrm{Cu} \cdot \mathrm{Pc}$ and Blue
19 on cellulose are now under study.

In conclusion, Blue 19 has the highest fastness to the simultaneous effect of light and perspiration in VS dyes examined and the other dyes have more or less some drawbacks.

\subsection{Self-excited Reduction of VS Dyes}

In the photoreduction of azo dyes in DL-mandelate solution, van Beek et al. ${ }^{13-20)}$ assumed a primary pro. cess where the excitation of DL-mandelate was follow. ed by the extraction of hydrogen by azo group of dye from the DL-mandelate occurred. While Pacifici and Irick $^{21,22)}$ supported this scheme, Bartholomew and Davidson ${ }^{25-27)}$ proposed a different scheme shown in Scheme 1.

In order to confirm the self-excited reduction of VS dyes on fading by use of the $\mathrm{DL}$-mandelate substrate, Toshiba filters, $Y-50(>500 \mathrm{~nm}), \mathrm{R}-60(>600 \mathrm{~nm})$ and $R-63(>630 \mathrm{~nm})$, were used to expose only Red 22 or Black 5 and to shield DL-mandelate at the same time. The results are shown in Table 2.

Table 2 Values of $A / A_{0}$ for VS Dyes on Cellulose in Anaerobic Sodium DL-Mandelate Solution $\quad(0.10$ mol/ $\mathrm{dm}^{3}$ ) by using Toshiba Filter

\begin{tabular}{|c|c|c|c|c|c|}
\hline & Filter & & $Y-50$ & $\mathrm{R}-60$ & $R-63$ \\
\hline Time & of exposure & & $10 \mathrm{~h}$ & $20 \mathrm{~h}$ & $20 \mathrm{~h}$ \\
\hline & & Yellow & 1.00 & - & - \\
\hline Singl & dyeing & Red 22 & 0.912 & 0.915 & 0.917 \\
\hline & & Black 5 & 0.842 & 0.849 & 0.757 \\
\hline Mix & Yellow & Yellow & 1.00 & 1.00 & 0.996 \\
\hline ture & $+\operatorname{Red} 22$ & Red 22 & 0.932 & 0.949 & 0.949 \\
\hline dye- & $\operatorname{Red} 22+$ & Red 22 & 0.975 & 0.964 & 0.948 \\
\hline ing & Black 5 & Black 5 & 0.954 & 0.853 & 0.779 \\
\hline
\end{tabular}

In spite of shielding the UV-region, self-excited reductive fading was observed for Red 22 and Black 5 in the anaerobic solution. This seems to show that the primary process for the fading of dyes is not attributed to the excitation of DL-mandelate but to that of dyes. This fact was further confirmed by comparing the values of $\mathrm{A} / \mathrm{A}_{0}$ for three dyes on cellulose dyed singly with those dyed in mixture. The values for three dyes in the single dyeing were close to those in the mixture dyeing. Variation in the value of $A / A_{0}$ for Red 22 and Black 5 by shielding with various fil- 


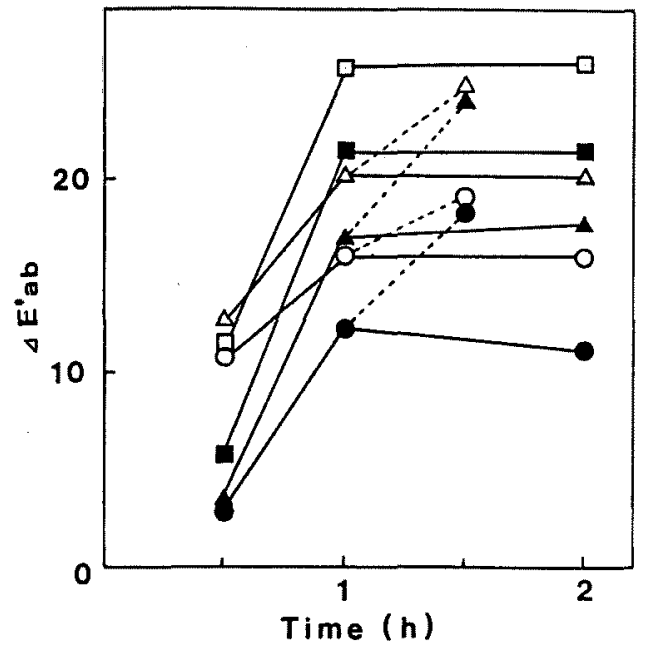

Fig. 6. Effect of sodium DL-mandelate on fading of C. I, Reactive Red 22 and Black 5 after soaking the cotton dyeings (Exposed by L 0888 A method, Estimation by $\Delta E^{*} a b, 1.0 \%$ o. w. f.). Plots at the exposure time at 1.5 $\mathrm{h}$ show the values of $\Delta \mathrm{E}^{*} \mathrm{ab}$ for each sample after re-exposure for $0.5 \mathrm{~h}$ after spraying water over the exposed sample for $1 \mathrm{~h}$.

\begin{tabular}{cccc}
\hline Na DL-mandelate $\left(\mathrm{mol} / \mathrm{dm}^{3}\right)$ & 0.01 & 0.02 & 0.05 \\
\hline Red 22 & 0 & $\Delta$ & $\square$ \\
Black 5 & $\bigcirc$ & $\Delta$ & $\square$ \\
\hline
\end{tabular}

ters supports clearly the self-excitation mechanism. No photoreduction of dye occurs by the sensitization of partner dye.

\subsection{Photoreduction of VS Dyes on Fabrics}

The rate of fading for Red 22 and Black 5 on cotton fabrics immersed in lactate solution before exposure was proportional to the concentration of lactate. ${ }^{12)}$ There are some evidences that the photoreduction of dye on cellulose occurs on exposure if they contain amines, ${ }^{23.24)}$ histidine ${ }^{31)}$ and lactic acid. ${ }^{12)}$

In order to check the similarity between the photo. reductive fading of VS dyes on cellulose film in subs. trate solutions and that on cotton fabrics, the fading of Red 22 and Black 5 on cotton immersed in DL-mandelate solution before exposure was examined. The rates of fading of two dyes were proportional to the concentration of DL-mandelate and that of Red 22 was larger than that of Black 5 (Fig. 6). These be haviors are similar to the fading of dyes on film in aqueous solutions. However, the effect of $\mathrm{DL}$-mande- late on the values of color difference $\Delta \mathrm{E}^{*}{ }_{\text {ab }}$ for both dyes on exposure was only observed in the early stage of exposure. DL-Mandelate showed no such behavior in the aqueous solution. Spraying water on the fabrics exposed for $60 \mathrm{~min}$ showed further variation of $\Delta \mathrm{E}^{*}$ ab. As in the case of oxygen which will be mentioned below, this behavior may be due to small diffusion coefficient of DL-mandelate in dry state and the acceleration by humidity.

The values of psychometric chroma coordinate $a^{*}$ for Black 5 on fabrics immersed in sodium DL-mandelate solution changed to negative after exposure for 1 $\mathrm{h}$, which showed reddish color. This is the same effect as sodium lactate but not as lactic acid. ${ }^{12}$ )

In order to examine the effect of oxygen on the fading of VS dyes on cotton fabrics, Black 5 on the fabrics immersed previously in sodium lactate solution was exposed by 'A' method of JIS L 0888 in atmos. pheres of nitrogen, air and oxygen. There was little effect of oxygen and nitrogen on the rate of fading for Black 5 irrespective of the presence of lactate (Fig. 7). Drying of the immersed fabrics before exposure decreased the rate of fading which was accelerated by the humidity. The results of blank test for Black 5 showed that the initial fading was significant and that the subsequent rate of fading was very small (Fig. 7).

These fading behaviors can be explained by small diffusion coefficient as well as low solubility of ox. ygen in cellulose. Since both of them are accelerated by the presence of humidity or largely by the swelling of water, water may increase the rate of fading on cellulose. When exposed in the presence of substrate such as lactate and DL-mandelate, dyes on dry cellulose may at first consume almost all oxygen in cellulose and then be subject to the reductive fading due to very slow penetration of oxygen. In the presence of substrate, therefore, cellulose mainly shows the reductive fading, while in the absence of substrate it protects dyes from rapid oxidative fading.

\section{SUMMARY}

The photobleaching of VS dyes on cellulose in $\mathrm{DL}$-mandelate or lactate solution is attributed to the photoreduction of azo group in dyes. The difference between the photo-oxidation and the photoreduction for Red 22 and Black 5 was caused by the difference 


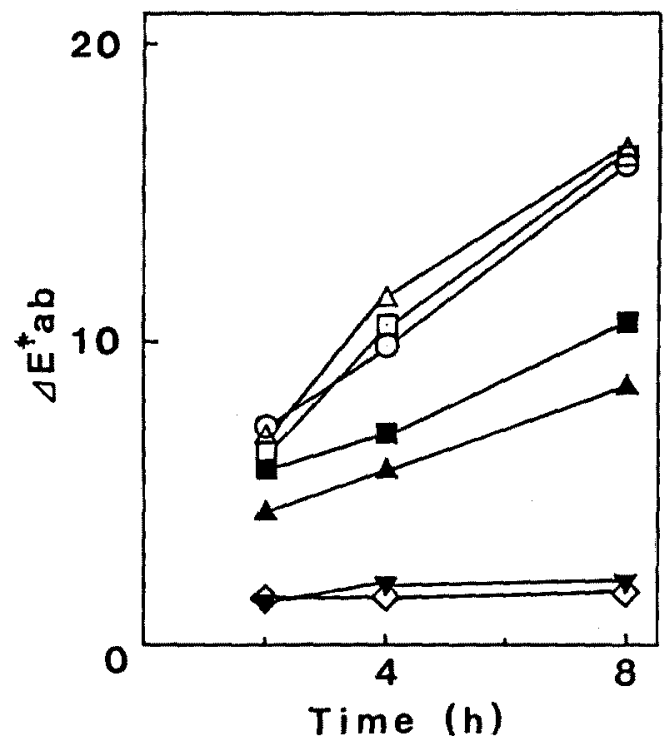

Fig. 7. Effect of sodium lactate $\left(0.05 \mathrm{~mol} / \mathrm{dm}^{3}\right)$ on the fading of C. I. Reactive Black 5 after soaking the cotton dyeings (Exposed by L 0888 A method, Estimation by $\Delta E^{*} a b, 1.0 \%$ o. w. f. dye) when exposed in air $(O)$, in oxygen $(\triangle)$, in nitrogen $(\square)$, in dry air with silica gel after drying ( $\mathbf{\Delta})$, and at $100 \% \mathrm{RH}$ without drying ( $\boldsymbol{\square}$ ); and the effect of exposure for the blank test (without soaking in the lactate solution) when exposed in dry air with silica gel $(\nabla)$ and at $100 \% \mathrm{RH}$ without drying $(\diamond)$

between the absorption spectra of irradiated product on cellophane after exposure, by the presence of amino group in the photoreduced product on cellulose, and by the absence of azo coupling to the photooxidized product in cellulose. The self-excited photoreduction mechanism of dye was confirmed to occur in the presence of substrate in water. The extent of interaction of VS dyes with substrates varied considerably with dyes and substrate. The oxidative and reductive fading of VS dyes on fabrics occurs through the same mechanism in aqueous solutions, although there are some differences in fading behavior.

\section{ACKNOWLEDGMENTS}

The authors would like to thank Sumitomo Chemical Co. Ltd. and Mitsubishi Chemical Corporation for assistance in preparation of this paper.

\section{REFERENCES}

1) T. Niwa, Kako Gijutu, 8, 303 (1973)

2) W. B. Achwal and V. G. Habbu, Man-made Text. India, 29, 286 (1986)

3 ) JIS L 0888-1977, Testing Method for Color Fastness to Light and Perspiration, Reaffirmed 1982 and modified 1988

4) T. Kosugi, T. Kakegawa, and S. Nishimura, Shizuoka-ken Hamamatsu Sen’i Kogyo Shikenjo Hokoku, No. 16, 68 (1978); No. 17, 6 (1979)

5 ) T. Sekiya, K. Yoshikawa, and O. Hirasa, Kenkyu Hokoku-Sen'i Kobunshi Zairyo Kenkyusho, 128. 111 (1981)

6) F. Ohtsuka, K. Itoh, and K. Fukawa, Senshoku to Kako, 22, (1), 17 (1979)

7) K. Imada. ATTS Reports, No. 12, 5 (1984); No. 13,5 (1984)

8) T. Urahata, H. Noshi, and K. Noda, Desanto Sports Kagaku, 7, 74 (1986); 8, 32 (1987)

9) T. Urahata, and S. Abeta, ATTS Reports, No. 28. 3 (1987); No. 29, 7 (1987)

10) JIS L 0848-1974, Testing Method for Color Fastness to Perspiration

11) Y. Okada, T. Kato, H. Motomura, and Z. Morită, Dyes Pigm., 12, 197 (1990)

12) Y. Okada, M. Hirose, T. Kato, H. Motomura, and Z. Morita, Sen-i Gakkaishi, 45, 399 (1989)

13) H. C. A. van Beek, and P. M. Heertjes, J. Soc. Dyers Colour., 79, 661 (1963)

14) H. C. A. van Beek and P. M. Heertjes, J. Phys. Chem., 70, 1704 (1966)

15) H. C. A. van Beek, P. M. Heertjes, C. Houtepen, and D. Retzloff, J. Soc. Dyers Colour, 87, 87 (1971)

16) H. C. A. van Beek, P. M. Heertjes, and K. Schaafsma, J. Soc. Dyers Colour., 87, 342 (1971)

17) H. C. A. van Beek, P. M. Heertjes, and A. A. M. Rutges, J. Soc. Dyers Colour., 89, 389 (1973)

18) H. C. A. van Beek, P. M. Heertjes, and K. Schaafsma, Rec. Trav. Chim. Pays-Bas, 92, 1189 (1973)

19) G. Heijkoop and H. C. A. van Beek, Rec. Trav. Chim. 95, 6 (1976)

20). G. Heijkoop, G., and H. C. A. van Beek, Rec. Trav. Chim. 96, 83 (1977)

21) J. G. Pacifici and G. Irick, Jr., Tetrahedron Lett., 
2207 (1969)

22) J. G. Pacifici, G. Irick, Jr., and C. G. Anderson, J. Am. Chem. Soc., 91, 5654 (1969)

23) G. Eigenmann, Helv. Chim. Acta, 46, 298 (1963)

24) G. Eigenmann, Helv. Chim. Acta, 46, 855 (1963)

25) R. F. Bartholomew and R. S. Davidson, J. Chem. Soc. (C), 2342 (1971)

26) R. F. Bartholomew and R. S. Davidson, J. Chem. Soc. (C), 2347 (1971)

27) R. F. Bartholomew, R. S. Davidson, P. F. Lambeth. J. F. McKellar, and P. H. Turner, J. Chem. Soc. Perkin 2. 577 (1972)

28) S. G. Cohen, A. Parola, and G. H. Parsons, Jr., Chem. Rev., 73, 141 (1973)

29) A. G. Kepka and L. I. Grossweiner, Photochem. Photobiol., 14, 621 (1971)

30) R. Nilsson, P. B. Merkel, and D. R. Kearns, Photochem. Photobiol., 16, 117 (1972)

31) J. W. Cumming, C. H. Giles, and A. E. McEachran, J. Soc. Dyers Colour., 72, 373 (1956)

32) I. B. C. Matheson, R. D. Etheridge, N. R. Kratowich, and J. Lee, Photochem. Photobiol., 21, 165 (1975)
33) Y. Okada, M. Hirose, T. Kato, H. Motomura, and Z. Morita, Dyes Pigm. in press

34) C. S. Foote, "Singlet Oxygen", Ed. by H. H. Wasserman and R. W. Murray, Academic Press, New York, 1979, Chap. 5

35) W. F. Smith, Jr., J. Am. Chem. Soc., 94, 186 (1972)

36) R. H. Young and R. L. Martin, J. Am. Chem. Soc., 94, 5183 (1972)

37) M. Koizumi and Y. Usui, Mol. Photochem., 4, 57 (1972)

38) M. Koizumi, S. Kato, N. Mataga, T. Matsuura, and Y. Usui, "Photosensitized Reactions", Chap. 7, p. 191, Kagakudojin Publishing Co. Inc., Kyoto. Japan, 1978

39) B. E. Blaisdell, J. Soc. Dyers Colour., 65, 618 (1949)

40) J. Griffiths and C. Hawkins, J. Chem. Soc. Chem. Commun., 463 (1972)

41) J. Griffiths and C. Hawkins, J. Chem. Soc. Perkin 2, 747 (1977)

42) J. Griffiths and C. Hawkins, J. Appl. Chem. Biotechnol., 27, 558 (1977)

\section{セルロース上の反応染料の光一汗複合効果による退色機構}

セルロース上に拈けるビニルスルホン系(VS)反応染 料の光汗複合効果による退色を, JIS L 0888法で染色布 を露光し，また染色フィルムを種々の水溶液中で露光し て嘼ベた。染色フィルムをDL-マンデル酸ナトリウム および乳酸ナトリウムの空気飽和水溶液中で露光する と，顕著な退色がみられ，例外を除き，その嫌気性溶液 中で洨，さらにその退色が促進されだ。マンデル酸など の基貿を含む嫌気性溶液中における染色フィルムの退色
大妻女子大学家政学部 岡田 㚣代 - 加藤 東京農工大学工学部 本村 洋美・森田 全三

は，光励起された染料の基質による光還元である。これ らの基質と酸素の雨方を含む溶液中の露光では，酸素や 基質の濃度及び杂料と基質の種類に依存して，一重項酸 素メカニズムによる光増感酸化及び/または光還元が起 こることを確かめた。人工汗液にあらかじめ浸漬し， JIS L 0888法で露光した綿織物上のVS 染料の退色は, それと同じ溶液中で露光した染色フイルム上の退色と機 構的に同じであることも示した。 